(2) 210

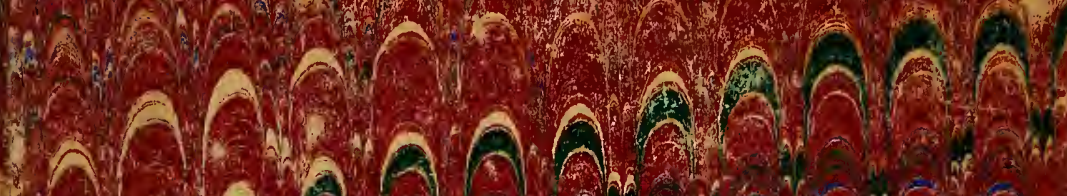
Wa

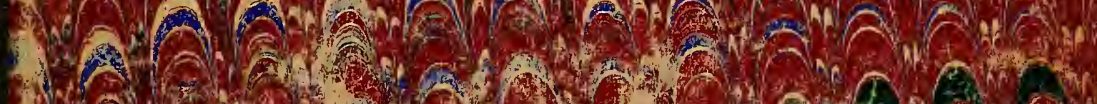

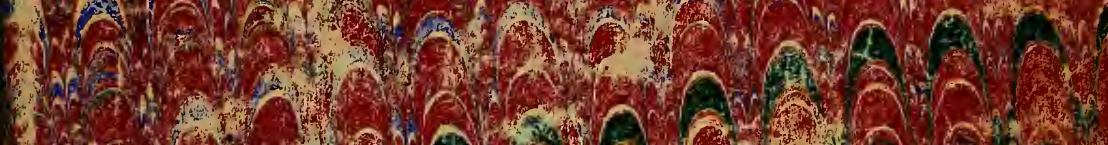

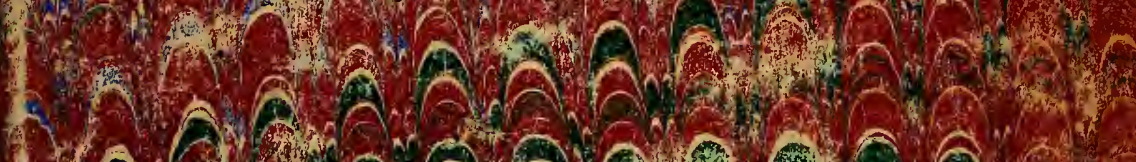
13 (3)

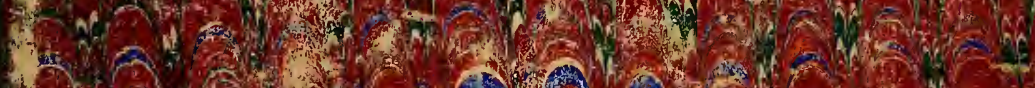

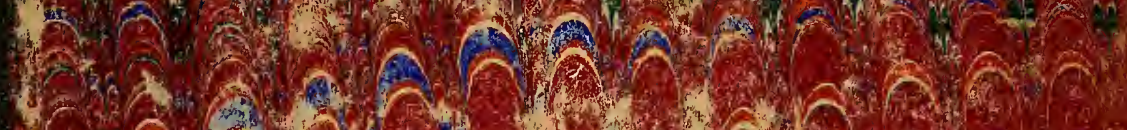

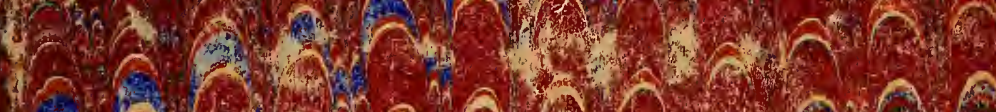

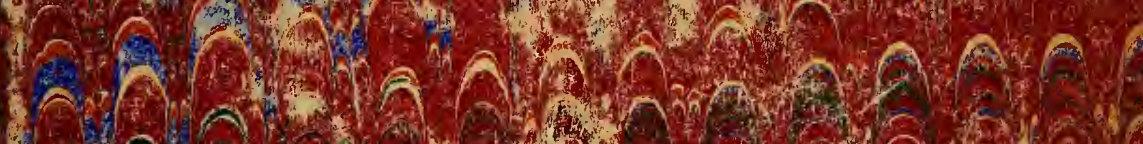

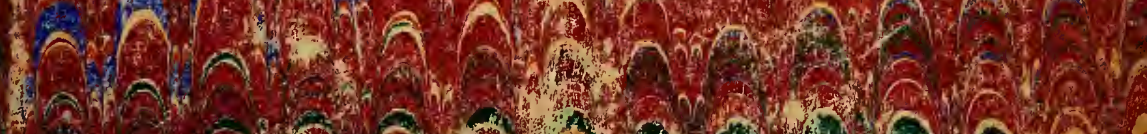

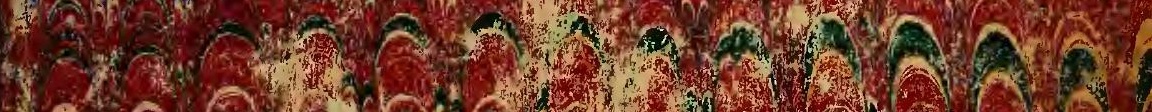

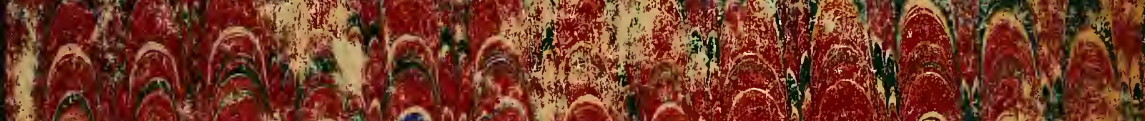

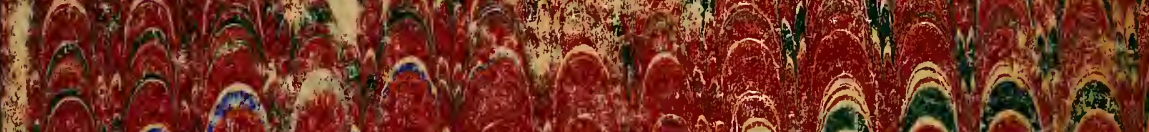

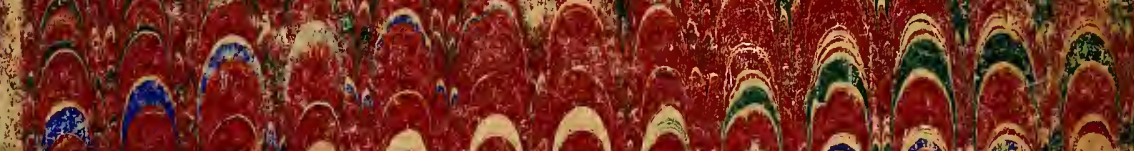
4.

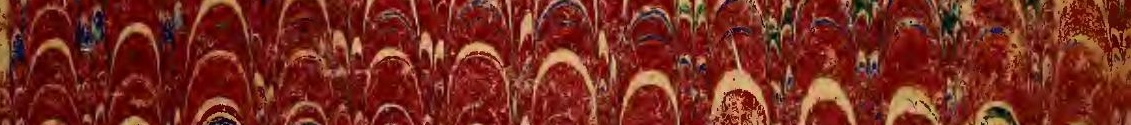

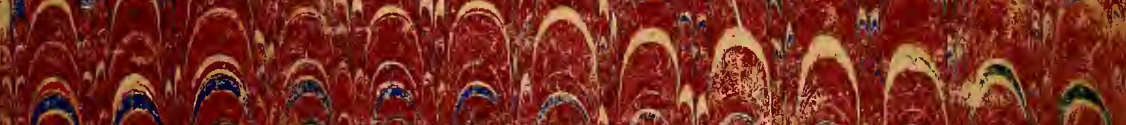

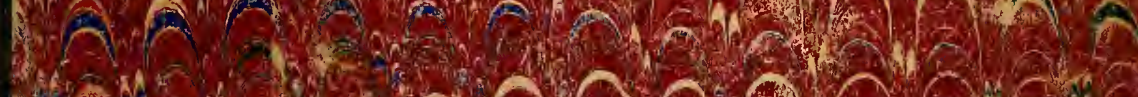

S451
M4W55

$1878 x$

(2) . 


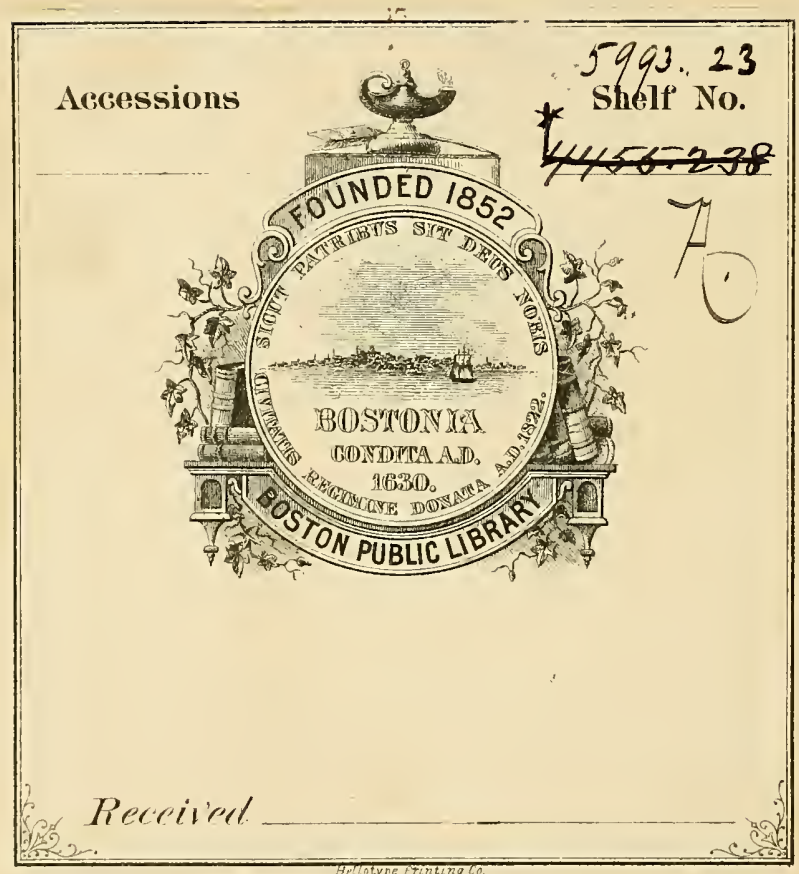


FEB 24011 
Digitized by the Internet Archive in 2010 with funding from Boston Public Library 


\title{
HISTORY AND PROGRESS
}

OF THE

\author{
M A S S A C H USETTS
}

\section{STATE BOARD OF AGRICULTURE}

Jor the ditist Q Quarter of a Centuru,

\author{
WITH A \\ REPORT ON FRUITS,
}

AT THE ANNUAL MEETING, FEB. 5, 1878.

BY

MARSHALL P. WIIDER.

1878.

$$
\text { BOSTON : }
$$

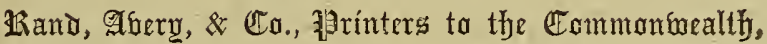
117 Franiklin Street. 


Hparshary dotscleter 


\title{
HISTORY AND PROGRESS
}

OF THE

\author{
MA S A C H U E T TS
}

\section{STATE BOARD OF AGRICULTURE}

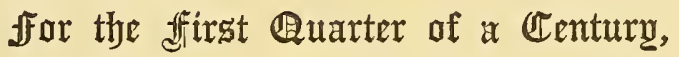

WITH A

\section{REPORT ON FRUITS,}

AT THE ANNUAL MEETING, FEB. 5, 1878.

BY

MARSHALL P. WILDER.

1878.

BOSTON :

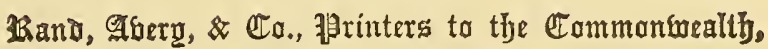
117 Franklin Street. 
my'194 


\title{
HISTORY AND PROGRESS OF THE BOARD.
}

\author{
BY MARSHALL P. WILDER.
}

Gentlemen, - With the close of this session, the first quarter of a century in the history of the Massachusetts Board of Agriculture will have terminated. In view of this fact, and also that only one member of the original Board, and Secretary Flint, are present with us on this occasion, and that he who now addresses you will soon be numbered among those who will have passed beyond the river, to work with you no more, I lave thought it proper to submit a few thoughts in regard to the history and progress of the Board, although at the risk of repeating some things I may have stated before. The results of our labors are so fully set forth in the beginning of the secretary's report, and in former reports, as scarcely to need an additional remark, except by way of confirmation. And what I shall say, I beg may not be considered as valedictory for myself or for the Board: God only knows when the time shall arrive for the utterance of these. As for the Board, we believe it will speak for itself for many years to come.

Anterior to its establishment, very little united action had taken place between the agricultural societies of our own or other States of the Union for the purpose of creating State Boards of Agriculture. But the example of Massachusetts and a few other States produced a change in public sentiment, which has resulted in great improvement. True, there were agricultural societies in many of our States, some of which still live in a grcen old age, and are actively at work with us; but there were no State Boards of Agriculture, with representatives, constituting, as they now do, departments for great agricultural influence and importance. It is also true that there were many illustrious examples of men, who, as pioneers, were endeavoring to establish the importance of science as especially applicable to agriculture; but it was not 
until the appointment of Henry Colman of Massachusetts as a State Commissioner in 1836, that such improvement took definite shape; and, notwithstanding his reports were suspended in 1840, they are now regarded as treasures of great practical knowledge, especially those in regard to the character of our soils, the reclamation of waste lands, and the adaptation of crops. These awakened a more thorough examination into the subject; and the seed then sown finally germinated, and produced the Central Board of Agriculture. This was organized March 20, 1851, Marshall P. Wilder as president, Henry W. Cushman and John W. Lincoln as vice-presidents, Allen W. Dodge corresponding, and Edgar K. Whitaker recording secretaries, with three delegates from each of the incorporated societies. At a meeting of the Central Board of Agriculture, Jan. 14, 18j2, it was resolved to petition the Legislature in the following resolution :-

"Resolved, That, inasmuch as agriculture is the chief occupation of her citizens, the Commonwealth, in the organization of her government, should be provided with a department of agriculture, with offices commensurate with the importance of the duties to be discharged, and the labors to be performed."

This action resulted in the establishment of the present State Department, which succeeded the Central Board of Agriculture.

This Act was passed in the session of 1852 ; and Mr. Flint entered upon his duties as Secretary of the Board in February, 1853, which office he has filled with signal ability and fidelity for a quarter of a century, and with honor to the Commonwealth, having fully justified the unqualified indorsement of Hon. Edward Everett, president of Harvard College at the time of his graduation, who earnestly recommended him for election.

One of the best things which Massachusetts has ever done to advance the cause of agriculture was the creation of this Department of Agriculture, and locating the office of the secretary at the Capitol. This has been a source of great convenience to the public, as reliable information can there be obtained from the best sources, and where the secretary is always at his post. This centre of information lias become of great importance, where persons have been put in com- 
munication with one another, so as to be able to obtain particular classes of stock, positions on farms, as foremen, \&c. It is a convenience to both parties. This, in future, will be more recognized and appreciated.

By the Act constituting the State Board, all the duties which had been performed by the secretary of state in regard to agricultural matters now clevolved on the secretary of the Board of Agriculture. This new and independent system of operations was established, whereby the secretary became the chief officer and organ of the Board, on whom has devolved ever since the duty of digesting the returns of the societies, and of preparing the ammual volume of the department. Thus the Board became the organ of the farming community, being placed near and connected with the government; so that the whole legislation in reference to bounties, premiums, and general agricultural interests of the State, has been controlled or influenced by the department; and thus by its operations it was also brought into friendly communication and reciprocal relations with the various local agricultural associations of the Commonwealth and country, dispensing to them, and receiving in return, valuable information for the benefit of the public.

Few are aware of the salutary influences which the Massachusetts Board of Agriculture has exercised on the farming community and the public mind during the period of its existence. An entire and complete change has taken place in public opinion with regard to the paramount importance of agricultural education. There are some here who remember, at the time of the organization of the Board, the great prejudice which existed against what was then termed "book farming;" and there were but ferv papers or periodicals that would boldly stand forth as champions of the cause.

But, amidst all the discouragements, here was sustained and cherished the first general efforts for the establishment of an agricultural college, now so favorably known and appreciated ; and here, ever since, it has been fostered and encouraged as one of the most important branches of education, receiving the patronage of the government, and good will of the people. Almost an entire revolution has taken place in the received principles and practices of cultivation during the existence of the Board; and much of this can be traced to 
the investigations of its members and the publication of their experience, thus not only teaching each other, but making the knowledge of one the property of all.

And here it may be stated, that, twenty-five years ago, the agricultural literature of the country was far from being creditable to us. Most of the works of ability were reprints of English publications, and were not generally read, or adapted to our location. The Board has contributed largely to the improvement of the agricultural literature of the country, raising it to a much higher standard of merit, until now it stands on a par with that of any other science.

Among the labors of the Board it should also be remembered that it early instituted an elaborate series of farm experiments.

It originated the law for the protection of sheep, which has also been adopted by many other States.

It effected legislation for the organization and encouragement of farmers' clubs, which are now so popular and useful.

Twenty years ago it was, clifficult to get an audience of farmer's to listen to the most distinguished scientific men, like Agassiz and Johnson: now farmers will go great distances to hear lectures from such men upon agriculture.

It originated the law for the inspection of fertilizers, and appointed the State agricultural chemist.

And, as a crowning glory, it arrested the progress of that dreadful scourge, the pleuro-pneumonia, and extirpated it from our State. Had it not been for the united and persistent action of the Board, it probably would here, as in Europe, have devastated not only our own, but other States, at a loss of hundreds of thousands, if not millions, of dollars. But who that is cognizant of these facts can doubt that this action of the Board with reference to that disease was worth more to the State and the country than many times the cost of our department from the beginning, or the expenses of sustaining it longer than any of us shall live?

In regard to the influence of the Board we have a striking illustration of the power of association as stated by Mr. Webster. "The great truth of the present generation," said he, "is that public implovements are brought about by voluntary combinations and associations." So it has been in the operations of this Board. 
It has brought together from time to time a band of the most intelligent, practical, and scientific co-workers that the State possessed, and it is to this centralization that we are much indebted for the progress we have made. If any one doubts this, let him examine the reports of the Secretary for the last quarter of a century, and I think he will have his doubts removed.

With the Report now in press there will have been published twenty-five yearly volumes, containing more than sixteen thousand pages of matter pertaining to agriculture and kindred pursuits, including numerous engravings of cattle, horses, swine, farm-implements, and other illustrations, some of which are of high character as works of art.

These annual volumes, embracing in all an issue of more than two hundred and fifty thousand copies, have gone forth not only to the farmers of this Commonwealth, but have been distributed throughout our own and foreign lands. They constitute a comprehensive library in themselves, embracing essays, reports, and discussions on almost every subject in agriculture, and are eagerly sought for with every issue.

These reports have greatly promoted the objects for which the Board was established, and extended its influence far and wide. No similar publication, within my knowledge, contains more practical and useful information for farmers. Complete sets have already become valuable, and are more and more apreciated. By these reports young men have been stimulated to become farmers; and by the example of the Board, and the correspondence of its members, other States have been led to establish State Boards of Agriculture on our plan.

Nor must it be forgotten, that, from the first, the Massachusetts State Board have been the firm friends of agricultural education, and have always co-operated heartily for the advancement and welfare of the agricultural college, whose influence is now beginning to be felt, not only at home, but in the far-off islands of Japan, where, to the honor of our Commonwealth, William S. Clark, the president of her agricultural college, has erected the first agricultural college of Japan, and installed in its faculty (under the auspices of that nation) a president and two professors, all of whom were gradrates of the Massachusetts Agricultural College. 
Gentlemen, I have spoken with freedom; for I have co-operated with this Board from its inception, and am familiar with its operations. I have ever felt a deep interest in the agriculture of Massachusetts, especially in the welfare and usefulness of this department; and I think facts fully substantiate the statements I hare made. I have therefore thought it but just to submit to you my views in regard to what it has accomplished in the first quarter of a century of its existence. This I have done, without any intention of magnifying its importance, and only for the purpose of rendering justice to those who assisted in laying its foundations, and also to those who have labored with us for its advancement. Most of its progenitors have been removed from their earthly mission. Only one of the original members (he who now addresses you) and Mr. Secretary Flint are now connected with the Board. Nearly all the rest of the twenty original members constituting the Board have passed away. If any think I have spoken too favorably of the Board, or what it has accomplished in the first twenty-five years of its existence, let them compare the condition of agriculture at the time of its organization with the subsequent improvement, in well-defined and systematic knowledge, of the present day.

When we consider the embarrassments which most institutions have to labor under in their early history, I think we may regard the operations of the Board as reasonably successful. Our movements are in the right direction; and in the future as in the past, time will greatly promote the prosperity and wealth of the State.

For myself, I clesire to be thankful that I have been permitted to witness the progress already made by the Board. Soon all of those who were banded together at its organization will have ceased from their labors on earth ; but I rejoice that I have lived to see the doubts and opposition of that day pass away, and the Board receive, as it does, the public favor and the fostering care of the government. But we cannot stop here. Mnch has been accomplished; but greater results are to be attained. We have but just entered the field which Massachusetts is to occupy in the successful cultivation of her lands; and we confidently believe the time may not be distant, when science shall have improved the arts of cultivation to its utmost extent, and we shall better understand the 
laws which govern it; when, by a better knowledge of the constituents and capacities of our lands, a proper division of labor, a wise selection of crops and the constituents for fertilizing them, we may be enabled to compete favorably with the richer lands of the West.

This review of our work should be satisfactory. Much of - our progress is the result of individual exertion; but, after all, the grand motive-power is associated effort. Let us, then, take fresh courage, and work right onward for the advancement of our cause, thus receiving and disseminating information for the benefit of all. And as you come up, from year to year, from all parts of our Commonwealth, with the results of your observation and experience, may you have the satisfaction of believing that you have done and are doing something to increase the wealth, happiness, and prosperity of the people of our beloved Commonwealth.

On motion of Major Phinney it was unanimously

Voted, That the thanks of the Board be presented to Col. WILDER for the highly interesting facts in regard to the history and the operations of the Board for the last quarter of a century. 


\section{REPORT ON FRUITS.}

BY MARSHALL P. WILDER.

In accordance with the request of the Board, I have the pleasure to submit the following Report. Although it has been generally considered that the climate of Massachusetts is somewhat unfavorable to the cultivation of fruits, excepting the apple, it is found that the enterprise and indomitable perseverance of her sons compel her unfertile soil to yield some of the finest fruits that are produced in any part of the world; and it is safe to say, that nowhere else in the Union are finer specimens of the apple, the pear, the strawberry, and occasionally other fruits, to be seen, than at the exhibitions of the Massachusetts Horticultural Society. By the enterprise and perseverance of the cultivators of Massachusetts, many of the most popular varieties in our country have been raised from seed, constituting some of the most desirable sorts for wide and general cultivation.

With the close of this year, half a century will have passed since the organization of the Massachusetts Horticultural Society, from which has emanated, more than from any other source, the remarkable extension of fruit-culture which now permeates and enriches our whole land. In few things is progress more apparent than in the advancement of pomological knowledge on this continent. I have on many occasions spoken of this; but I have thought it might not be inappropriate, now, at the close of the first quarter of a century in the history and operations of this Board, to allude again to the remarkable

EXtension OF FrUit-CULTURE, AND THE IMMENSE CROPS OF OURCOUNTRY.

At the time of the organization of that society, the cultivation of fruits for the market, or for exportation, was limited to a few states. In the year $1816 \mathrm{Mr}$. Coxe, the first 
great American pomologist, thought the fine apple-growing section bounded by the Mohawk River in the North, and the James River in the South. Fruit-growing in this State was confined principally to apples and peaches. But very few of the latter found their way to the markets of the North ; while strawberries and other small fruits were scarcely to be seen, except in the locality where they were raised.

Now, the culture of fruits has extended from Canada to the Gulf of Mexico, and from the Atlantic to the Pacific coast. Almost every steamer from New York for Liverpool or London, in the fall and winter months, takes apples, varying from five hundred to three thousand barrels. Shipments have been made from other ports; and, as late as last May, there were fifteen hundred barrels sent to England from Philadelphia. In December last ninety thousand barrels of American apples were landed at Liverpool. These exports have varied much in yearly amounts, occasioned by scarce or abundant seasons. In 1861 the amount was only $\$ 269,000$; in 1871 it was $\$ 509,000$; while for the year ending June 30 , 1877 , it amounted to $\$ 2,937,025$, - as kindly furnished me by Dr. Young, chief of the Bureau of Statistics, - showing an increase of more than five hundred per cent in five years. Very little difficulty is experienced in the winter months; but arrangements have been made to ship in warm weather by vessels with refrigerator compartments.

As the refrigerating process becomes more and more perfect, it will aid largely the exportation, not only of apples, but of more delicate fruits. Pears, peaches, and grapes have been sent to England in good order; and it is confidently expected that American peaches will soon be well known in the markets of England.

How great the progress! Massachusetts, in fruit-culture as well as in other departments of educational and industrial life, has been a great leader; and from her has emanated, in the early history of American pomology, more than from any other source, the wide-spread interest that has distinguished our land.

Now, Canada, Iowa, Wisconsin, Minnesota, Kansas, Nebraska, California, Oregon, and other new States and Territories, where the cultivation of fruits had scarcely commenced when this Board was established, have made exhibitions of 
fruit at the various sessions of the American Pomological Society in Richmond, Boston, Chicago, and at the Centennial, which have astonished the world with the progress made. Thirty years ago, when this society was formed, the area of fruit-culture and the value of our fruits was so limited, that it was not thought worth while to collect the statistics. Then many states, Canada, and Nova Scotia, had given but little attention to fruit-culture, except that of apples. These and other sections were deemed too far north for successful fruit-cultivation. Now they produce large quantities of fine fruits, even in the cold northern regions; the Nova Scotia Society having received four medals from the Royal Horticultural Society in London, and the Ontario Society, at the quarter Centennial session in Boston in 1873, the Wilder Medal, for the best collection of fruits.

The estimate by the government for the Centennial, last year, furnished the following statistics of the fruit-culture of our country:-

The number of acres under cultivation in orchards, vines, and small fruits, is estimated at 4,500,000. The number of trees is estimated as follows: apples, 112,000,000; pears, $28,260,000$; peaches, $112,270,000$; grapes, $141,260,000$; total, $393,790,000$. The estimated value of fruit products is, apples, $\$ 50,400,000$; pears, $\$ 14,130,000$; peaches, $\$ 56,135,000$; grapes, $\$ 2,118,900$; strawberries, $\$ 5,000,000$; other fruits, $\$ 10,432,800$; making a grand total of $\$ 138,216,700$, or nearly equal to one-half of the value of our average wheat-crop. California, to say nothing of figs, oranges, olives, and almonds, has sixty thousand acres of vineyards, and forty-three millions of vines yielding annually, besides grapes and raisins for the market, ten millions of gallons of wines, to which may be added the wines of Missouri, Ohio, and other states; the whole annual wine product being fifteen millions of gallons.

The following are a few illustrations of the immense quantities of fruits which are sent to market in addition to what is consumed at home.

Of strawberries, there were received in one day in the New-York market, at the height of the season, from all sources, seven thousand crates, - more than ten thousand bushels. The crop of peaches raised in this country is so enormous that we hardly dare state the quantity. The 
largest crop was in 1875; and, on the peninsula of Delaware and Maryland alone, it was estimated at between seven million and eight million baskets.

From California, there were sent east, in 1876, three hundred and thirty-four car-loads of fruit, of four hundred bushels each.

The increase of strawberry culture in the vicinity of Norfolk, Va., is astonishing, completely heading the page of horticultural progress. The shipments this year have been over three millions of quarts. There were nearly ten thousand pickers in the field in one day. One grower had a hundred and eighty-five acres. To Boston alone there have been shipped this year 11,547 crates, of forty-five quarts each, or more than sixteen thousand bushels.

The increase in the crops of apples in New York, Michigan, and the more Western States, is wonderful.

From New York, it is estimated, that, in abundant years, a million and a half of barrels are exported in addition to those consumed at home. One county, it is said, received one million a year of dollars for apples sold; a single firm at Boston receives from that State from thirty thousand to forty thousand barrels of apples per year.

The immense collection of fruit shown at the Centemnial Exposition last year, surpassing even the great exhibitions of the American Pomological Society at Boston and Chicago, deserves mention here. One of the judges writes me, "I know that the judges examined over twelve thousand dishes of fruit during the week, commencing the 10th of September, and I have no doubt that the entire exhibition during the season reached the grand number of over sixty thousand. dishes and over four hundred thousand specimens."

In view of the wonderful progress which has already been made, we begin to realize the great importance of American pomology; nor should we forget, as among the great benefits of fruit-culture, the employment of thousands of men, women, and children, or the immense amounts paid for freight on fruits to railroads, steamboats, \&c., and the profits to dealers.

But who can estimate the amazing quantities of "fruits that are to be produced on this continent, when the lands suited to fruit-culture are brought into use! Look at the 
vast amount of these in the eastern slope of our country, and, still more wonderful, the land on the Pacific slope! Of these, California alone has a territory eight hundred miles in length and two hundred miles in breadth, - three times as large as all of the New-England States, four times as large as the State of New York or Pennsylvania, - having millions of acres for fruit-cultivation.

Some have feared that there might be an over-production of fruit; but the whole crop may now be saved and utilized by the new methods which are being constantly invented for curing and distributing this surplus. In fruit districts large amounts of capital are invested in establishments for the drying and canning of fruits, which promise to put the surplus of abundant seasons in condition for preservation till wanted for consumption or exportation. Some of these are yet to be tested; but no doubt exists that we shall eventually thus utilize our fruits, and make them not only profitable, but a source of increasing revenue.

The perfection now attained in the drying and canning process - possessing the great advantage, for transportation, of reducing the weight three-fourths or more by the removal of water, and rendering it capable of shipment to all climes, and of being preserved perfectly for years - will, in all probability, overcome this difficulty, which only occurs on bearing and abundant years. The demand abroad for dried fruits is very large, and is daily increasing. The exports for the year ending June 30,1877 , were $14,318,052$ pounds; and, if they can be afforded at a little less price, it is thought it would be enormous. England, Germany, and Australia would be great purchasers. Besicles, we are constantly inventing new methods for preserving fruits by preparations in various nutritious and elegant forms, which might absorb our abundant crops, and take the place of those unhealthy preserves and sweetmeats in which our markets abound, and which are so injurious to the health of our people.

By the production of new varieties from seed, we have not only secured native kinds adapted to evęry section of our country, but varieties which have prolonged the season of fruits in some sections, either by early or late kinds, for one or more months. Especially is this to be seen in the peach, grape, and strawberry; so that many of our markets are supplied for a much longer period than ever before. 
By the introduction of early peaches, the season for this fruit has been advanced nearly a month. From South Carolina and Georgia shipments were made last year to northern markets as early as May 25; and, by a wise selection of early and late peaches, Mr. Berckmans, president of the Georgia Horticultural Society, states that peaches may now be had from May to November. Similar illustrations might be given of the prolongation of the season of the strawberry, the grape, and the pear, in our markets; those of the north being now supplied with the strawberry from the first of May to the middle of July, and with the grape, the pear, and the apple, from the first of July until April or May. And why may not those who have the means supply their tables with fruits in some form through the year? Some of us already enjoy this luxury, beginning with the strawberry, and following, in succession, with the other small fruits, the grape, the pear, and the apple; thus furnishing a circle of fruits which delights the eye, gratifies the taste, improves the health, and crowns our daily meals throughout the year.

\section{FRUITS FOR MASSACHUSETTS.}

But to confine our observations to Massachusetts. I would state, that, with the exception of a few new seedling varieties, the same standard sorts as have been mentioned in previous reports still continue to be most prominent for the market.

In regard to those best adapted to the various sections of the State, I would remark, that by dividing the State into three sections, having Boston, Worcester, and Springfield as their centres, we may arrive at pretty correct conclusions as to the fruits most approved of for general cultivation.

\section{EASTERN DIVISION.}

Apples. - Summer : Large Early Bough, Red Astrachan, and Williams. Autumn: Gravenstein, Porter, Foundling, Holden Pippin or Fall Orange of Downing, Mother, Lyscom, Hubbardston Nonesuch, and Cogswell. Winter : Baldwin, Rhode-Island Greening, Roxbury Russet, Hunt Russet, King of Tompkins County, Northern Spy (strong soil and high culture). Sweet Apples : Pumpkin Sweet, Ladies' Sweet, Danvers Winter, Tolman Sweet, Pound or Lyman Sweet. Many other varieties succeed well, but are only grown in small quantities; such as the Fameuse, Garden Royal, Maiden's Blush, Minister; and Washington Strawberry (a fine variety). 
Pears. - Early: Doyenné d'Été, Beurre Giffard, Clapp's Favorite, Brandywine, Manning's Elizabeth. Clapp's Favorite surpasses others of its season in size and beauty, and is, withal, of fine quality, everywhere increasing in popularity. Autumn: Bartlett, Belle Lucrative, Beurre Bosc, Beurre Hardy, Beurre Superfine, Beurre Clairgeau, Doyenné Boussock, Doyenné du Comice, Duchesse d'Angoulême on Quince, Goodale, Howell, Louise Bonne of Jersey on Quince, Merriam, Paradis d'Automne, Seckel, Sheldon, St. Michel Archange, Souvenir du Congrès (a very handsome, large pear, ripening quite as early as the Bartlett), Urbaniste on Quince. Late Autumn or Winter: Beurre d'Anjou, Dana's Hovey (small, very rich, comparing favorably with the Seckel in quality), Josephine de Malines (as late regarded with favor), Lawrence, Winter Nelis (fine, but too small for market). Cooking: Vicar of Winkfield (on rich, warm soils, with care in thinning: a good dessert variety), Catillac, Uvedales, St. Germain or Pound. New Varieties: The Mount Vernon (fine, late russet pear) is regarded with favor. The same may be said of Clapp's (No. 22, now Frederick Clapp), also of the President and Admiral Farragut, raised by the late Dr. S. A. Shurtleff. The Emile d'Heyst is a fine foreign, rare variety. Souvenir du Congrès is a very beantiful, large pear, quite as early as the Bartlett. The Beurre Diel and Flemish Beauty, like the White Doyenné, once so popular, are being discarded on account of cracking (occasionally they are as fine as ever). The orchards of Massachusetts, especially in the eastern part of the State, abound in fine varieties of the pear. The above constitute the principal popular varieties in market; but, of all the sorts introduced within the last fifty years, no kind surpasses, in its combined characteristics of excellence, the Beurre d'Anjou. It increases in popularity every year, and with proper care is susceptible of being kept in fine condition for two or three months. Of the thousand or more varieties which I have proved in the forty-six years of experience, no other has given me so much satisfaction. It is also found, by the catalogues of the American Pomological Society, to succeed well in more than thirty of our States and Territories. And I think I may be allowed to say, without personal merit or motive, if I have done nothing else for the pomology of our country, that the introduction of this pear thirty-eight years ago was a blessing to our land.

Grapes. - Few new varieties have been introduced of late. Those old sorts most approved of around Boston and in the eastern section of the State are the Hartford, Concord, Creveling, Delaware, Diana, Lindley (Rogers No. 9), Massasoit (Rogers No. 3), Wilder (Rogers No. 4). Barry (Rogers No. 43) is a fine kind, similar to the Wilder in size, appearance, and quality. There are a few new varieties which are regarded as giving good promise; among which, especially, is to be mentioned Moore's Early, a seedling of the Concord. It is very prolific and constant in crop, ripening fully two weeks before the Concord, growing beside it. The bunch is large and handsome; berry larger than the Concord, and equal in quality. It has been exhibited for several years before the Massachusetts Horticultural Society, and was awarded last fall a prize of sixty dollars for the best new seedling grape. It is considered a valuable acquisition for the 
north. The Worden, a new native variety, ripening earlier, and considered of better quality, than the Concord, by Mr. Hadwen of Worcester and Mr. Adams of Springfield, is being introduced around Boston. The Champion, as an early grape, is attracting some attention, ripening a week before the Hartford, of fair quality, very hardy, vigorous, and prolific. Hon. E. W. Bull, the originator of the Concord, Hon. George Haskell of Ipswich, and several other gentlemen, each presented seedling varieties at the exhibition of the Massachusetts Horticultural Society, some of which are of good pronise.

Strawberries. - New varieties, some of excellent character, are coming to notice every year. The older kinds that carry off the prizes of the Massachusetts Horticultural Society are Charles Downing, Jucunda, Hovey's Seedling (now forty years old; being the first successful attempt at improving the strawberry), President Wilder, Seth Boyden, Triomphe de Gand, and Wilson's Albany. The last is not regarded as of good quality, but is valuable for its productiveness. Among the new varieties which are attracting attention may be named the Belle, Caroline, and Hervey Davis.

\section{CENTRAL DIVISION.}

From the Annual Report of the Worcester-county Horticultural Society, a society second only to the Massachusetts for wealth, activity, and influence in New England, it will be seen that most of the fruits grown in the eastern section of the State are alike successful in the central. Mr. Hadwen, our associate member, reports the following :-

Apples. - Summer: Red Astrachan, Williams, Duchess of Oldenburg, and Sweet Bough. Autumn: The Gravenstein, Porter, Twenty Ounce, Hubbardston Nonesuch, Cogswell, Maiden's Blush, Pumpkin Sweet, Leland Spice. Winter: Baldwin, Rhode-Island Greening, Yellow Bellflower (on warm, rich soil), Ladies' Sweet, Leicester Sweet, Roxbury Russet. He also regards with favor the Sutton Beauty, Worcester Spy, Foundling, Washington Strawberry, Mother Apple, Holden Pippin, McLellan, Tetofsky, Sterling, Washington Royal or Palmer Greening, (" having as many desirable qualities as any apple"), nearly all of which originated in Worcester County, and are of excellent quality, yielding abundant crops. The soil and climate of Worcester County are especially adapted to fruit-culture, and has long been .celebrated for the apples it has produced from seed, such as the Hubbardston Nonesuch, Holden Pippin or Fall Orange of Downing, Mother, Washington Royal or Palmer Greening, Sutton Beauty, Foundling, Worcester Spy, Leicester Sweet, and probably the Twenty Ounce or Cayuga Red Streak. Mr. Hadwen, in his excellent essay on the apple, states that the cultivation of the apple has long been an important interest in Worcester County; the moneyvalue received in 1876 for apples exported, probably exceeding the value of any other product.

Pears. - Nearly all the sorts named in the list of approved kinds for Boston and the Eastern Division are alike adapted to the central section of the State. Reference, therefore, may be had to the list already given. $\mathrm{Mr}$. James Draper, an intelligent nurseryman of Worcester, in his essay 
on the pear, regards with special favor Clapp's Favorite, Bartlett, Sheldon, Beurre d'Anjou, Beurre Bosc, Belle Lucrative, Lawrence, Duchesse d'Angoulême, Louise Bonne of Jersey, Doyenné du Comice, the three last named on quince.

Grapes. - Most of the grapes which succeed elsewhere at the north are on trial here. The most noticeable old and popular sorts are the Concord, Hartford, Delaware, Diana, Eumelan, some of Rogers's Hybrids, and the Worden, originating in Western New York.

Strawberrirs. - The "Essay on the Strawberry" of Mr. William H. Earle, an eminent cultivator, states that the most profitable kinds are the Charles Downing, Jucunda, and Wilson's Albany. Amateurs are growing all the new varieties. Of the profits of strawberry culture Mr. Earle remarks, "If one takes interest in the business, he will be surprised at the possible results. On about three acres of land I realized a gross income of a little over two thousand dollars."

\section{WESTERN DIVISION.}

Mr. John W. Adams, an intelligent cultivator of Springfield, regards the following as leading sorts :-

Apples. - Summer: Red Astrachan, Duchess of Oldenburg. Autumn: Porter, Gravenstein. Winter: Baldwin, Hubbardston Nonesuch, Tompkins County King, Northern Spy, Rhode-Island Greening. Sweet Apples: Sweet Bough, Orange Sweet, Talman Sweet.

Pears. - Summer: Doyenné d'Été, Manning's Elizabeth, Clapp's Favorite, Bartlett, Belle Lucrative, Doyenné Boussock, Duchesse d'Angoulême, Louise Bonne of Jersey, Onondaga, Seckel, Beurre Bosc, Lawrence, and Winter Nelis.

Grapes. - The grape-culture, Mr. Adams remarks, is still confined to a few varieties which have proved themselves best adapted to this locality. Among those classed for hardiness, vigor, and productiveness he names Concord, Clinton, Champion, Hartford, Ives, Martha, and Worden. $\mathrm{He}$ regards the Champion or Talman, which is the same, as the best very early grape, and the Worden as much prized, and earlier than the Concord. Of the Concord, Mr. Adams remarks, "A single vine, eight years old, on my own place, allowed to grow at random, ripened this year a quantity estimated to exceed three thousand bunches, equalling in sweetness and flavor those that came from the South."

Stra w berries. - Mr. Adams states that the cultivation of the Strawberry is increasing. The kinds most approved of are Charles Downing, Col. Cheney, Kentucky, Nicanor, Seth Boyden (No. 30), and Triomphe de Gand. The Duncan is attracting attention on account of its earliness and richness, and the Monarch of the West for its size and productiveness.

THE PRESERVATION AND RIPENING OF FRUITS.

In regard to the preservation and ripening of fruits there is very little new to be reported. The conditions of success are now pretty well understood. Our farmers who raise 
apples in large quantities know how to do it; but with delicate fruits, such as the pear and grape, more care is requisite.

The ripening of fruit depends on saccharine fermentation: this is followed by other fermentations, as the vinous and acetous. To prevent these, and preserve fruit in all its beauty, freshness, and flavor, the temperature must be uniform, and kept below the degree at which the fermentation, or ripening process, commences. Mr. Robert Manning in his prize essay many years ago said, "The ripening of fruit is the completion of the chemical process by which starch is transformed into sugar, and is the first step toward fermentation or clecay : therefore whatever promotes fermentation will hasten the ripening; whatever retards fermentation will tend to its preservation."

The conditions of success may be briefly stated as follows: The perfect control of temperature, light, and moisture. Numerous structures have been built both in our own and other countries for this purpose; and all experience shows that these conditions must be complied with, or success cannot be attained: hence these apartments must be cool, and constructed so as to exclude at pleasure the external atmosphere, which starts fermentation. After many years of experience, both with and without the use of ice, I have adopted a house built in a cool, shady aspect, with door on the north, and with a thoroughly drained and cemented cellar whose windows may be opened or closed at pleasure. In this way I am enabled to keep my late fall and winter pears until February or March in good condition. Apples may be kept at a lower temperature than pears, say thirty-four to forty degrees. In such a cellar, our associate member, Mr. John F. Brown of Lunenburg, has kept Baldwins to the middle of June, when he has realized as high as from six to nine dollars per barrel. Mr. Brown barrels his apples, and places them immediately in his cellidr, where he has control of the temperature.

Late fruits may remain on the trees until severe frosts are feared, but should be gathered with great care. Summel pears should be picked some days before the ripening process commences. A summer pear ripened upon the tree is generally inferior. In respect to the latter Mr. Patrick 
Barry has so aptly expressed my own opinion, that I use his language: "The process of ripening on the tree, which is the natural one, seems to act upon the fruit for the benefit of the seed, as it tends to the formation of woody fibre and farina. When the fruit is removed from the tree, at the commencement of ripening, and placed in a still atmosphere, the natural process seems to be counteracted; and sugar and juice are elaborated instead of fibre and farina." Thus pears which become mealy, and rot at the core, if left on the tree to ripen, are juicy, melting, and delicious when ripened in the house. In regard to the use of ice, I would say, that, where fruits are kept for some months under its influence at a low temperature, they seem to lose much of their flavor: the cellular tissue also seems to have become dry, and to have lost its vitality, or power to resume the ripening process. Experience proves, that, for the common varieties of the pear, about forty degrees of Fahrenheit is the temperature best suited to hold this process in equilibrium. The proper maturing of fruit thus preserved demands skill and science. Different varieties require different degrees of moisture and heat according to the firmness of the skin, the texture of the flesh, and the natural activity of the juices. Thus some varieties of the pear will ripen at a low temperature and in a comparatively dry atmosphere, while others are improved by a warm and humid air. Some varieties of the pear ripening with difficulty, and formerly esteemed only second-rate, are now pronounced of excellent quality, becanse the art of maturing them is better understood. Great improvement has taken place in the handling, packing, and preservation of fruits; so that they are delivered in perfect condition from distant places, every class of fruit having its suitable style of package. This remark also applies to the packing of trees for foreign countries; so that trees shipped by Ellwanger \& Barry, Rochester, N.Y., to Australia, after one hundred and fifty-three days, arrived in good condition. So well is the art of keeping grapes now understood, that we have the Concord from Fitchburg and other towns in that vicinity, and from New Hampshire, in such fine order as to command twentyfive cents per pound in December and January.

The pear-tree blight has been more prevalent in several localities around Boston, for the last two years, than ever 
before, and we are as much in the dark as to the cause and remedy as are others; but we trust, that, like former visitations of this malady, it will prove only temporary. In some instances the apple has been affected in the same manner.

In closing this Report I beg to state that the importance of the fruit-crop of Massachusetts has not been fully appreciated. Of the apple alone the returns of 1874 gave us 3,252,057 bushels, valued at $\$ 1,450,252$; Worcester County having produced in the same year 933,013 bushels, valued at $\$ 380$,000 . Similar results have been realized in other sections of the State, not only with the apple, but with other fruits.

When we reflect on what Massachusetts has done for the cause of American pomology in the last half-century, I think we should feel well satisfied. To Massachusetts the world is indebted for many of its best fruits. There is the Baldwin apple, the Roxbury Russet, the Williams and Hubbardston Nonesuch apples, and the Clapp's Favorite, Dana's Hovey, and other pears. Nor must it be forgotten that Massachusetts was the first to introduce from Europe the Bartlett and the Beurre d'Anjou pears, so popular throughout the whole country. In her soil originated the Hovey's Seedling strawberry and the President Wilder. To these may be added the Diana, Rogers, and other grapes, and last, but not least, the Concord, which has overspread our hills and valleys from one end of the continent to the other. Other states and societies have done nobly; but Massachusetts, as a pioneer in the early history of our pomology, has wielded a strong influence. Strike out from our catalogues the fruits which Massachusetts has introduced from Europe; root out from our orchards, gardens, and vineyards the fine native fruits which have originated in our cold and rough soil, - and we should require a long list of valuable kinds to fill their place. Massachusetts has more good fruits stored up in the laboratory of her resources. Her mission is not yet ended. Let us help her to fulfil it. 



\section{SOME OF THE}

\section{Prineipal 9 ublished $W$ ritings}

or

MARSHALL PINCKNEY WILDER.

1835. 1878. 


\section{Historical Addresses and Lectures.}

Observatious on the Camellia and its Varieties, with an acconnt of its introduction into Great Britain and this comntry.

The Hybridization of the Camellia and its Varieties.

1835.

On Laying the Corner Stone of the First Massachusetts Horticnltural Hall, Boston.

Speeches at the Triennial Festivals of the Massachusetts

Horticultural Society, with Valedictory, after eight years' service as President

Before the Sons of New Hampshire, at their First Celebration, Nor. 7 , Boston.

On the Reception of the Members of the New Hampshire Legislature-Obsequies of Webster, Boston.

As President of the Sous of New Hampshire, at their Second Celebration. Nov. 2, Boston.

speech for the Wilders, at the 200th Anniversary of the incorporation of the town of Lancaster, Mass.

1853.

As President, on the Celebration of the 225th Anniversary of the Settlement of Dorchester.

$185 \check{5}$.

As Commander of the Ancient and Honorable Artillery Company, Faneuil Hall, 219th Anuiversary, June.

As President of the Sons of New Hampshire, on the Reception of the Second Regiment of New Hampshire Volunteer's on the march to the Battle-Field, Boston, June ?20. 1861.

speech on the Fortieth Anniversary of the Settlement of Rer. Amos W. Burnham, D.D., Rindge, N. H.

speech as Representative of the Grand Lodge of Massachusetts at the World's Conrention of Freemasons, in Paris, France.

Sonthern IIorticultural Tonr.

Speech at Plymonth at the Celebration of the 250th Anniversary, Landing of the Pilgrims.

Lecture on California, in Music Hall, Boston, and in various other cities.

Response at the Centennial Celebration of the St. Andrew's Lodge, Boston, in Behalf of the Survivors of Four Thousand Freemasons of Boston and Vicinity, who Signed the Declaration in 1831. 
Speech at Banquet given to Grenadier Guard Band, of Lon-

don, at World's Peace Jubilee, Boston.

Speech at Banquet given to the Japanese Embassy, Boston, Angust 2.

1872 .

Speech on the Twenty-fifth Anniversary of Settlement of the

Rev. James H. Means, D. D., Dorchester, Mass.

1873.

Speech at the Bi-Centennial Celebration of Dunstable, Nashua, Oct. 27.

Speech at the 25th Anniversary of Essex Institute, Salem. 1873. Speech at the Centennial Celebration of the Battle of Lexington, April 19.

Speech at the Semi-Centennial Celebration of the town of Lowell, March 10.

Speech at the Centennial Celebration of the Massachusetts

Grand Lodge of Freemasons, as a Sovereign. Grand

Lodge, Independent of the Mother Country.

Anntial Addresses before the New England Historic Genea-

logical Society, Boston.

1868 to 1878.

Agricultural Adpresses.

Addresses and Speeches, before the Norfolk Society. 1849 to 1869.

Before the Bristol Society, Taunton.

1849.

Speech in Massachusetts Senate for an Agricultural College. 1850.

Before the Berkshire Society, at Pittsfield.

1851.

Before the Hampshire Society, Amherst, Mass.

1851.

Before the New Hampshire State Agricultural Society, at

Manchester.

Before the Massachusetts Central Board of Agriculture, Boston.

Before Rhode Island Society for the Encouragement of Domestic Industry, Providence.

As President of the Advisory Board of Agriculture, Washington, D.C.

Report of Commissioners to Massachusetts Legislature, concerning Agricultural Schools.

Lecture on Progress and Importance of Fruit Culture, New Haven, Conn. 
Report, as Chairman of United States Commission, on the Culture and Products of the Vine, at Paris Exposition. 1867.

Before the Massachusetts Board of Agriculture, at Framingham, on the History of the Board.

1869.

Valedictory Address before the Norfolk Agricnltural Society, after twenty year's' service as President.

1869.

Before Massachusetts Board of Agriculture, Pittsfield.

1870.

Speech at Re-union of Mass. Board of Agriculture, Boston. 1870.

Lecture on the Hybridization of Plants, Boston.

1872.

On the Progress and Influence of Rural Art, Fitchburg.

1872.

At the Graduation of the First Class of the Massachusetts Agricultural College, Amherst, Mass.

1871.

Before the Massachusetts State Board of Agriculture, on its Twenty-fifth Amiversary. Address and Report.

1878.

\section{Adpresses Before the American Pomological Soctety.}

On the Inauguration of the Society in New York, 1848. At the meeting in New York, 1849. At Philadelphia-Eulogy on Andrew Jackson Downing, 1852. At Boston, 1854. At Rochester, N. Y., 1856. At New York, 1858. At Philadelphia, 1860. At Boston, 1862. At St. Lonis, 1867. At Reception in Independence Hall, Address and Banquet, Philadelphia, 1869. At Reception in the Capitol, and Address, Richmond, Va., 1871. At BostonQuarter-Centennial Celebration, Reception in Fanenil Hall, Address, and Banquet, Music Hall, 1873. At Chicago, Ill., Address and Banquet, 1875. At Baltimore, Md., 1877.

Adpresses Before the United States Agricultural Society.

At its formation, Washington, D. C., 1852. At Washington, 1853. At the First Exhibition, Springfield, Mass., 1853. At Washington, 1854. At its Second Exhibition, at Springfield, O., 1854. At Washington, 1855. At its Third Exhibition, at Boston, 1855. At its Fourth Exhibition, at Philadelphia, 1850. At Washington, 1856, '57. At its National Field Trial of Reapers and Mowers, at Syracuse, N. Y., 1857. At its Fifth National Exhibition, Louisville, Ky., 1857. At Washington, Valedictory Arldress, after six year's' service as President, 1858.

For other witings, see Transactions of above-named Societies. 


\section{B I OGRAPH IES}

or

MARSHALL PINCKNEY WILDER. 



\section{B I O G R A P H I E S}

OF

\section{MARSHALL PINCKNEY WILDER}

MAY BE FOUND IN THE FOLLOTING PUBLICATIONS:

The Horticulturist; Downing. Vol. 3, p. 14.

1848.

Jourual of Agriculture: Vol. III., p. 529.

1848 .

Boston Atlas.

1851.

New Hampshire as it is.

1853.

Book of the Lockes; page 198.

1853.

Livingston's Eminent Men, page 513.

1854 .

Hunt's Merchants' Magazine.

1855 .

The Horticulturist. Barry; p. 111.

1855 .

The Happy Home. Vol. 3, p. 53.

1856 .

Tilton's Journal of Horticulture. Vol. 1, 1. 65. 1867.

New England Historical and Genealogical Register. 1867.

The Rural New Yorker. $\quad 1869$.

California Farmer, (June and July). 1870.

Biographical Dictionary, p. 982:. 1872.

'The London Gardener's Chronicle, p. 463.

Universal Biography. 1873.

Boston, Past and Present; p. 167.

The Chronotype, N. Y. ; p. 40.

History of Rindge ; p. 335.

Cyclopedia of Literature ; p. 841.

Richardson Memorial; page 777. 








\title{
Boston Public Library \\ Central Library, Copley Square
}

\author{
Division of \\ Reference and Research Services
}

The Date Due Card in the pocket indicates the date on or before which this bock should be returned to the Library. Plcise do not remove cards from this poc'set. 
BOSTON PUBLIC LIBRARY

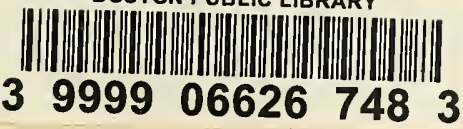




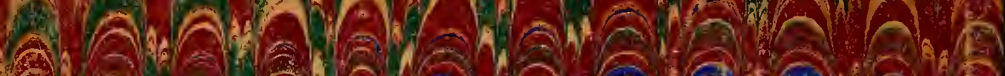

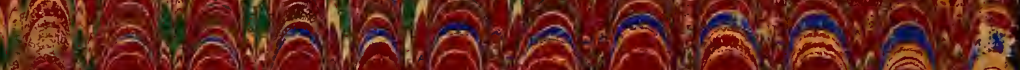
13)

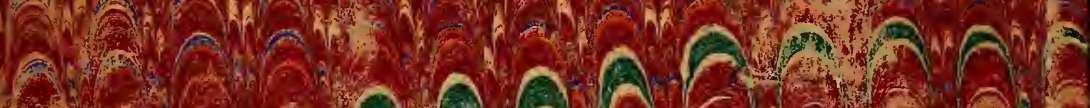

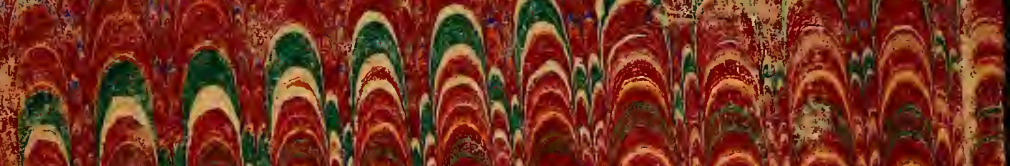
(3)

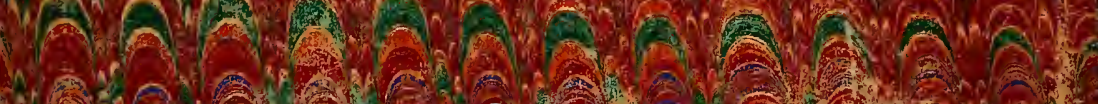

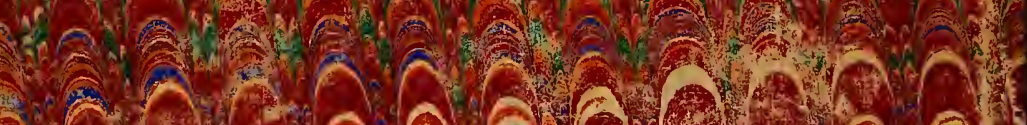

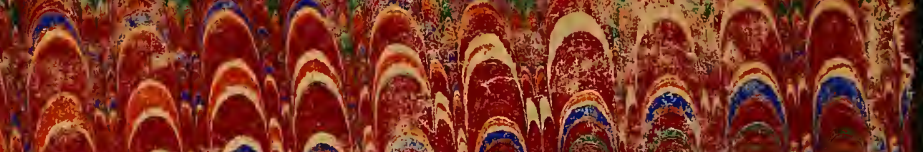

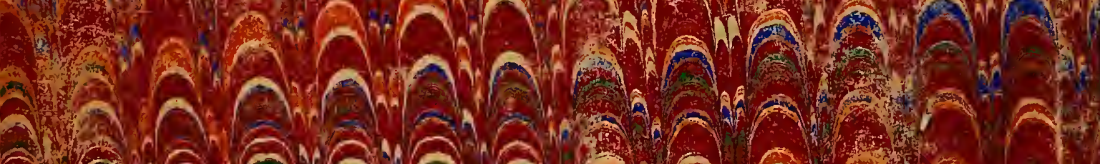
avin

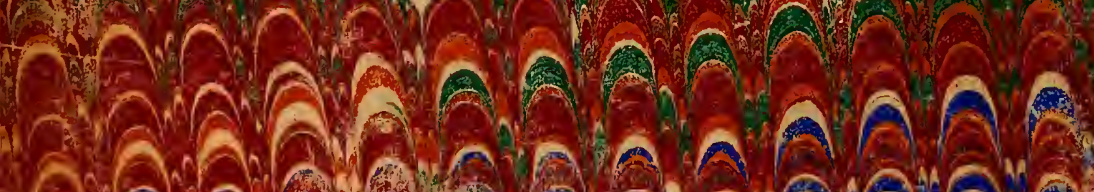

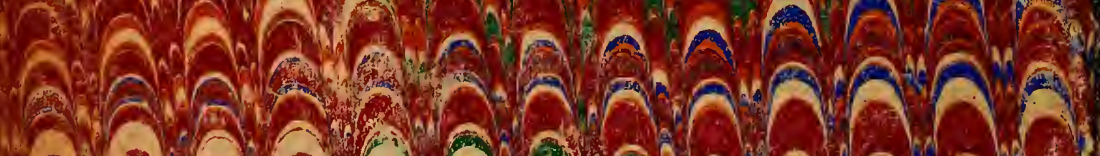
1.4.

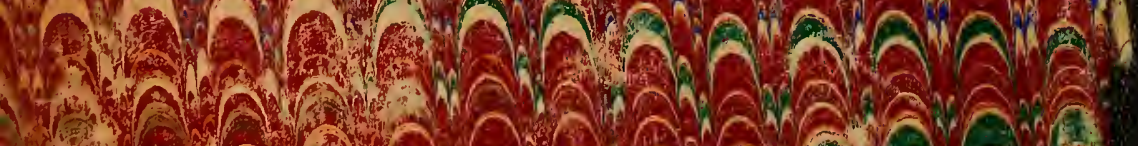

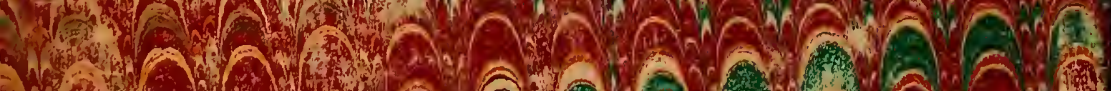
W. 1 m

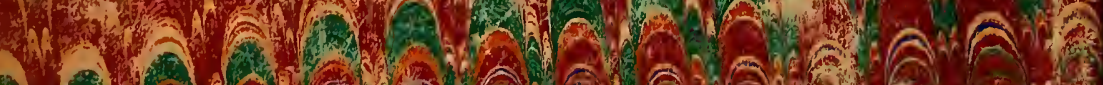

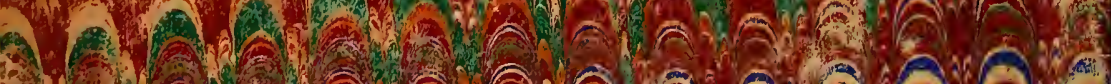

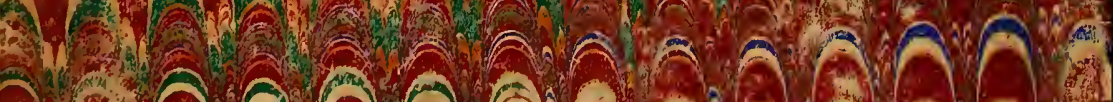

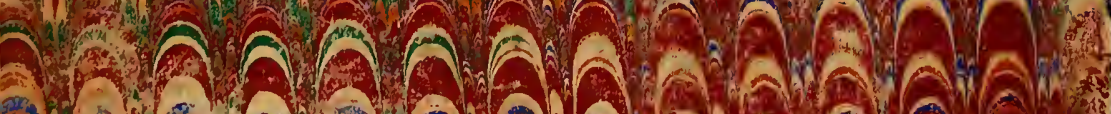
201.

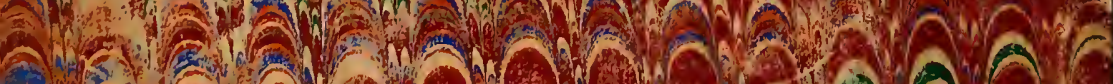
C. (A)

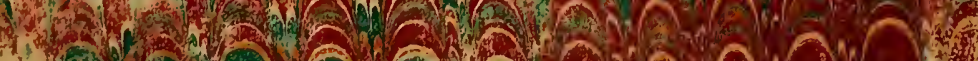

